\title{
Ethnic-racial inequity in health insurance in Colombia: a cross-sectional study*
}

\author{
Carlos Augusto Viáfara-López', Glenda Palacios-Quejada², and Alexander Banguera-Obregón ${ }^{3}$
}

Suggested citation Viáfara-López CA, Palacios-Quejada G, Banguera-Obregón A. Ethnic-racial inequity in health insurance in Colombia: a cross-sectional study. Rev Panam Salud Publica. 2021;45:e77. https://doi.org/10.26633/RPSP.2021.77

ABSTRACT Objective. Characterize the relationship between ethnic-racial inequity and type of health insurance in Colombia.

Methods. Cross-sectional study based on data from the 2019 Quality of Life Survey. We analyzed the type of health insurance (contributory, subsidized, or none) and its relationship to ethnic-racial status and predisposing variables (sex, age, marital status), demographic variables (area and region of residence), and socioeconomic variables (education, type of employment, income, and unmet basic needs) through simple and multivariate regression analyses. The association between ethnic-racial status and type of health insurance was estimated using odds ratios (OR) and their 95\% confidence intervals, through a multinomial logistic model.

Results. A statistically significant association was found between ethnic-racial status and type of health insurance. In comparison with the contributory system, the probabilities of being a member of the subsidized system were 1.8 and 1.4 times greater in the indigenous population $(\mathrm{OR} \times 1.891 ; 95 \% \mathrm{Cl}: 1.600-2.236)$ and people of African descent $(\mathrm{OR}=1.415 ; 95 \% \mathrm{Cl}$ : $1.236-1.620)$, respectively $(\mathrm{p}<0.01)$ than in the population group that did not identify as belonging to one of those ethnic-racial groups.

Conclusions. There is an association between ethnic-racial status and type of insurance in the contributory and subsidized health systems in Colombia. Ethnic-racial status is a structural component of inequity in access to health services and heightens the disadvantages of people and population groups with low socioeconomic status.

Keywords Health services accessibility; social determinants of health; socioeconomic factors; ethnic inequality; Colombia.

In Latin America, certain ethnic-racial groups ${ }^{1}$ have been systematically exposed to multiple forms of material and social deprivation that generally manifest as low socioeconomic status (2). Health inequity occurs when there are unjust, avoidable, or remediable inequalities between social groups (3).

\footnotetext{
1 Although from a biological standpoint humanity is one and indivisible, in this study the term "race" (and "racial") is used as a sociological concept developed on the basis of phenotypic differentiations and the physical appearance of people, which are used in many areas to classify and establish social hierarchies (1).
}

\footnotetext{
* English translation from the original Spanish manuscript revised by the authors. In case of discrepancy, the original version shall prevail. Access to original manuscript: https:// doi.org/10.26633/RPSP.2021.18

1 Economics Department, Universidad del Valle, Cali, Colombia. $\triangle$ Carlos Viáfara.López, carlos.viafara@correounivalle.edu.co
}

The scientific literature shows that ethnic-racial status plays a key role in the different manifestations of inequity that affect health (3-7). There is also consensus that socioeconomic position and type of health insurance are social determinants of health that influence access to and quality of health services in some ethnic-racial groups $(3,8)$. Several authors have shown that having or not having health insurance is the main factor in health access disparities between different ethnic-racial groups (8-10).

In Colombia, the 1991 Constitution reaffirmed the multiethnic and multicultural nature of the country. According to

\footnotetext{
2 Independent consultant, Bogota, Colombia

3 Universidad del Valle, Colombia.
} 
the 2005 Census, $10.4 \%$ of respondents self-identified as people of African descent, $3.2 \%$ as indigenous, $0.012 \%$ as Romani or Gypsy, and $86.1 \%$ did not identify as part of any of these ethnic-racial groups. The people included in these minorities have not had equal access to power, prestige, and resources (11, 12 ), and are characterized as having higher mortality, lower chances of survival when faced with disease (13), worse indicators of self-perceived health (14), worse health status $(14,15)$, insufficient health insurance (16), and less access to medical services (17-19).

Given that health insurance is a component of health service access (20), in 1993 the Colombian government passed Law 100 (21) to ensure that the most vulnerable populations have access to health services through what is called the subsidized regime (22). The other insurance system in Colombia, called contributory, is only for individuals with employment contracts or the ability to pay. Individuals who cannot afford to pay and are not yet affiliated with the subsidized regime are considered associate members (22). It follows then that a person's type of health insurance is associated with their social position and ability to pay.

Studies indicate that there are major differences in the use of health services among insured and uninsured individuals (23), as well as in populations insured through the contributory and subsidized regimes (24). The subsidized insurance system is associated with poor medical care (25) and reduced access to preventive primary care services and specialized consultations (26), a worse state of health and longer wait times to receive care (27), a higher incidence of poverty-related infectious and communicable diseases including malaria, and a higher risk of dying before the age of 5 (26). There are also extreme inequalities in sexual and reproductive health care (26).

Socio-economic deprivation is the main barrier to having adequate health insurance $(16,22,26)$ and full access to health services (27). However, there is insufficient literature that analyzes inequity due to ethnic-racial status based on socioeconomic position and affiliation with different health insurance systems. There are even fewer studies on improving welfare systems in Latin America and subsequently insuring a significant part of the vulnerable population currently associated with the subsidized system (28). The objective of this study is to characterize the relationship between ethnic-racial inequity and type of health insurance in Colombia.

\section{MATERIALS AND METHODS}

A cross-sectional study was conducted, based on data from Colombia's 2019 National Quality of Life Survey (ECV-2019) carried out by the National Statistics Department (DANE) (29).

The ECV-2019 is a primary source of direct and representative information on the country's households that is based on a probabilistic sample of 75,780 households selected using a multi-stage, stratified, and conglomerate design, according to 2005 census data. Of the 289,432 people aged 18 or older who were surveyed, $8.6 \%$ self-identified as people of African descent, $4.7 \%$ as indigenous, $0.03 \%$ as Romani or Gypsy, and $86.8 \%$ were individuals who did not identify with any of these ethnic-racial groups. Due to the low weighting of Romani or Gypsy populations, it was decided to exclude them from the study, and people with missing information were also eliminated, resulting in a final sample of 98,818 individuals. For calculation purposes, each observation was weighted by the inverse probability of being sampled in the ECV-2019 (29).

\section{Variables and measurements}

Type of health insurance was used as a dependent variable in this study: a) affiliation with the contributory regime, b) affiliation with the subsidized regime, and c) not affiliated with either of those two regimes.

Independent variables were selected from ECV-2019 survey questions about the individual factors that predispose and enable an individual to use health services, based on the Aday and Anderson model for accessing these services (20) and the social determinants of health proposed by Solar and Irwing (3).

Ethnic-racial status is considered a structural component of social determinants and is therefore a mediator of access to health services (3). This variable was based on answers to the question: "According to your culture, people, or physical traits, you are or identify as: (a) Indigenous; b) Gypsy (Romani); c) Raizal from the Colombian archipelago of San Andres, Providencia and Santa Catalina d) Palenquero from San Basilio; e) Black, Mulatto, Afro-descendant, Afro-Colombian; f) None of the above". For analysis purposes, these six categories were reduced to three: 1) indigenous: people who self-identified as such, 2) Afrodescendants: those who self-identified as Raizal, Palenquero, Black, Mulatto, Afro-Colombian, or Afro-descendant, and 3) those with no self-reported ethnicity (no-SRE), i.e. people who answered "None of the above." The self-reported ethnicity model used by DANE was used, which independently shows only ethnic-racial minorities and not people of European, Asian, or other descent who do not identify as part of the specific minorities mentioned.

The structural determinants or predisposing factors for accessing health services were sex, age (completed years), and marital status (in a formal or consensual marital union, or no marital union).

Demographic factors that enable an individual to access health services included the area of residence (municipal capital: the urban center where the mayor's office is located; populated area: a corregimiento [subdivision of a municipality], inspección de policía [smaller subdivision of a municipality], hamlet, parish, or agricultural area), and the region in which it is located.

Socio-economic position, which covers different aspects of social stratification (3), was estimated by the following variables: years of education (school years completed); type of employment (formal or informal); and employment income, quantified as the number of current monthly legal minimum wages. In 2019 the monthly minimum wage was $\$ 828,116$ Colombian pesos (30), equivalent to US $\$ 254.82^{2}$.

The variable "unsatisfied basic needs" (UBNs) was used to describe material circumstances, as stated: (a) inadequate housing; (b) homes with inadequate services; (c) households with school non-attendance; (d) critically overcrowded households; (e) households with high economic dependence (3) (Table 1).

\section{Statistical analysis}

A descriptive analysis was applied to the different category variables presented in the form of frequency tables;

The exchange rate as of January 1, 2019 was $\$ 3,249.75$ pesos per U.S. dollar (31). 
TABLE 1. Operationalization of the variables used in the Quality of Life Survey, Colombia, 2019

\begin{tabular}{|c|c|c|}
\hline Type of variable & Variables & Operationalization \\
\hline Dependent variable & Type of health insurance & $\begin{array}{l}\text { Contributory regime } \\
\text { Subsidized regime } \\
\text { No insurance }\end{array}$ \\
\hline Ethnic-racial status & Self-reported ethnicity/race ${ }^{\mathrm{a}}$ & $\begin{array}{l}\text { Indigenous } \\
\text { Afro-descendant }{ }^{\mathrm{b}} \\
\text { No self-reported ethnicity }\end{array}$ \\
\hline \multirow[t]{3}{*}{ Structural determinants } & Sex & $\begin{array}{l}\text { Male } \\
\text { Female }\end{array}$ \\
\hline & Age & Years of age completed \\
\hline & Marital status & $\begin{array}{l}\text { In a marital union (formal or consensual) } \\
\text { No marital union }\end{array}$ \\
\hline \multirow[t]{2}{*}{ Demographic factors } & Area of residence & $\begin{array}{l}\text { Urban } \\
\text { Rural populated area }\end{array}$ \\
\hline & Region of residence & $\begin{array}{l}\text { Bogotá } \\
\text { Atlantic } \\
\text { Eastern } \\
\text { Central } \\
\text { Pacific (not including Valle del Cauca department) } \\
\text { Antioquia } \\
\text { Valle del Cauca } \\
\text { San Andrés and Providencia } \\
\text { Orinoco-Amazon }\end{array}$ \\
\hline \multirow[t]{3}{*}{ Socioeconomic position } & Years of education & Years of schooling completed \\
\hline & Type of employment & $\begin{array}{l}\text { Formal } \\
\text { Informal }\end{array}$ \\
\hline & Employment income in terms of current legal monthly minimum wages ${ }^{c}$ & $\begin{array}{l}\text { More than } 3 \\
\text { Between } 2 \text { and } 2.99 \\
\text { Between } 1 \text { and } 1.99 \\
\text { Between } 0 \text { and } 0.99\end{array}$ \\
\hline Material circumstances & Unmet basic needs (UBNs) ${ }^{d}$ & $\begin{array}{l}\text { Lives in a household with no UBNs } \\
\text { Lives in a household with some UBNs }\end{array}$ \\
\hline
\end{tabular}

the chi-squared test $\left(\chi^{2}\right)$ was used to measure the association between discontinuous variables and the Student's t-test was used to compare averages in the continuous values.

For the multifactorial analysis of the association between type of health insurance and ethnic-racial status, a multinomial logistic model with regression of race-specific intercepts (32) was applied. Five models were estimated to test the robustness of the association between ethnic-racial status and the type of health insurance. After selecting the variables using a simple analysis by ethnic-racial status, sequential adjustments were made for structural determinants, sociodemographic characteristics, social position variables, and material conditions; odds ratios (OR) and their 95\% confidence intervals (95\%CI) were calculated.

The presence of a linear association between two or more independent variables, particularly due to the multidimensionality of ethnic-racial status and its interaction with other social variables (33), was investigated using the variance inflation factor (VIF) test: VIF values $\leq 3.0$ would indicate that multicolinearity is not a problem for estimating the model, although the general threshold is 10 (34).

As goodness-of-fit measures, we calculated the adjusted $R^{2}$ indicator, which measures the contribution of independent variables in the explanation of the dependent variable, from 0 (independent variables do not explain the dependent variable) to 1 (full explanation of the dependent variable), and the Wald test, which reflects the statistical significance of the variables or set of variables involved in the model; we concluded that these variables are important for explaining the dependent variable if $p<0.05$ (34).

Statistical analysis was carried out using Stata version $16^{\mathrm{TM}}(35)$.

\section{Ethical considerations}

The study employed a secondary database anonymized by DANE that meets all ethical requirements for human research according to international standards.

\section{RESULTS}

\section{Descriptive analysis}

Significant differences in the type of health insurance were observed based on ethnic-racial status (Table 2). The population with no self-reported ethnicity (no-SRE) had the highest level of insurance under the contributory regime (56.6\%), followed by Afro-descendants (36.7\%), and indigenous people $(17.8 \%)$ 
TABLE 2. Sociodemographic characteristics of the study sample ${ }^{\text {a }}$, Colombia, 2019

\begin{tabular}{|c|c|c|c|c|}
\hline Variable & $\begin{array}{l}\text { No self-reported ethnicity } \\
\qquad(\mathrm{n}=81,370)\end{array}$ & $\begin{array}{l}\text { Afro-descendant } \\
\quad(n=9,929)\end{array}$ & $\begin{array}{l}\text { Indigenous } \\
(\mathrm{n}=7,519)\end{array}$ & $p$ \\
\hline \multicolumn{5}{|l|}{ Health insurance regimen (\%) } \\
\hline Contributory & 56.6 & 36.7 & 17.8 & \multirow[t]{3}{*}{$<0.001^{\mathrm{d}}$} \\
\hline Subsidized & 36.1 & 57.0 & 77.1 & \\
\hline Unaffiliated & 7.3 & 6.3 & 5.1 & \\
\hline \multicolumn{5}{|l|}{$\operatorname{Sex}(\%)$} \\
\hline Female & 40.7 & 39.9 & 35.1 & \multirow[t]{2}{*}{$<0.001^{d}$} \\
\hline Male & 59.3 & 60.1 & 64.9 & \\
\hline \multicolumn{5}{|l|}{ Marital status (\%) } \\
\hline In a marital union & 57.9 & 57.5 & 63.5 & \multirow[t]{2}{*}{$<0.001^{\mathrm{d}}$} \\
\hline No marital union & 42.1 & 42.5 & 36.5 & \\
\hline \multicolumn{5}{|l|}{ Area of residence (\%) } \\
\hline Municipal capital & 83.5 & 69.6 & 34.0 & \multirow[t]{2}{*}{$<0.001^{d}$} \\
\hline Rural populated area & 16.5 & 30.4 & 66.0 & \\
\hline \multicolumn{5}{|l|}{ Geographical region (\%) } \\
\hline Bogotá & 20.8 & 3.3 & 2.1 & \multirow[t]{9}{*}{$<0.001^{d}$} \\
\hline Atlantic & 17.8 & 29.3 & 34.5 & \\
\hline Eastern & 21.4 & 1.3 & 2.4 & \\
\hline Central & 11.1 & 2.1 & 10.3 & \\
\hline Pacific (not including Valle del Cauca department) & 4.5 & 24.6 & 34.9 & \\
\hline Antioquia & 13.8 & 11.3 & 2.2 & \\
\hline Valle del Cauca & 8.1 & 26.7 & 6.4 & \\
\hline San Andrés & 0.1 & 0.8 & 0.0 & \\
\hline Orinoco-Amazon region & 2.4 & 0.6 & 7.2 & \\
\hline \multicolumn{5}{|l|}{ Type of employment (\%) } \\
\hline Informal & 57.4 & 67.1 & 81.7 & \multirow[t]{2}{*}{$<0.001^{d}$} \\
\hline Formal & 42.6 & 32.9 & 18.3 & \\
\hline \multicolumn{5}{|c|}{ Job income in current legal monthly minimum wages $(\%)^{\mathrm{b}}$} \\
\hline Between 0 and 0.99 & 55.8 & 70.0 & 82.1 & \multirow[t]{4}{*}{$<0.001^{\mathrm{d}}$} \\
\hline Between 1 and 1.99 & 29.0 & 23.6 & 14.0 & \\
\hline Between 2 and 2.99 & 5.7 & 3.1 & 2.1 & \\
\hline More than 3 & 9.5 & 3.3 & 1.8 & \\
\hline \multicolumn{5}{|l|}{ Unsatisfied basic needs (UBNs) ${ }^{c}(\%)$} \\
\hline Lives in a household with no UBNs & 91.6 & 82.0 & 61.7 & \multirow[t]{2}{*}{$<0.001^{d}$} \\
\hline Lives in a household with some UBNs & 8.4 & 18.0 & 38.3 & \\
\hline Years of education (average) & 10.4 & 9.1 & 7.5 & $<0.001^{\mathrm{e}}$ \\
\hline Age (years, average) & 39.9 & 39.4 & 39.1 & $\begin{array}{l}<0.001^{\dagger} \\
0.4273^{g}\end{array}$ \\
\hline \multicolumn{5}{|c|}{ 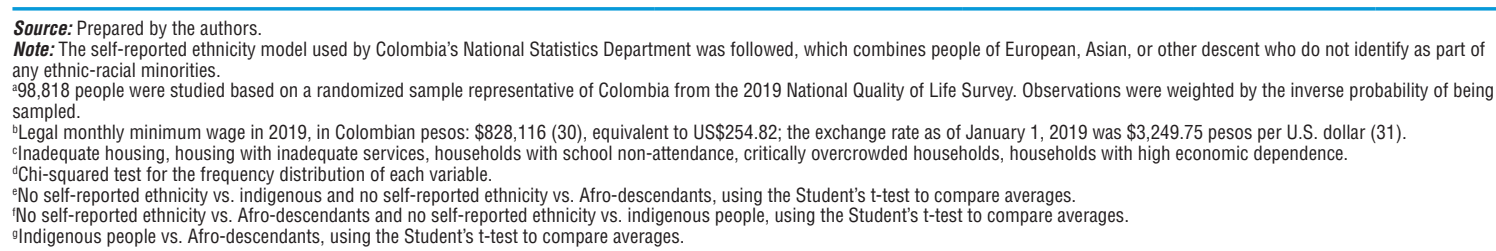 } \\
\hline
\end{tabular}

( $p<0.001$ among the three groups). An inverse relationship was observed in terms of affiliation with the subsidized regime: indigenous people showed the highest percentage $(77.1 \%)$, followed by Afro-descendants (57.0\%), and the no-SRE group (36.1\%) ( $p<0.001$ between the three groups). Paradoxically, in the uninsured population, people with no SRE had a slightly greater $(7.3 \%)$ but statistically significant presence in the three groups ( $\mathrm{p}<0.001)$, compared to Afro-descendants $(6.3 \%)$ and indigenous people $(5.1 \%)$.
Some predisposing factors did not show significant percentage point differences between certain ethnic-racial groups, although due to the size of the groups they were statistically significant among the three groups $(p<0.001)$ : the percentage of men and the population in a marital union was slightly higher among indigenous peoples (63.5\%), compared to Afrodescendants and those classified as having no SRE $(57.5 \%$ and $57.9 \%$, respectively). The average ages also showed some numerical similarity among the different groups (no-SRE: 
39.9 years; Afro-descendants: 39.4 indigenous people: 39.1 ), but with statistically significant differences between the no-SRE group and indigenous people and between the no-SRE group and Afro-descendants.

As for the factors considered to be enabling (area and region of residence), statistically significant differences $(p<0.001)$ were observed in the populations analyzed. The largest percentage in rural populated areas were indigenous peoples $(66.0 \%)$, followed by Afro-descendants (30.4\%), and people with no SRE $(16.5 \%)$. The majority of indigenous peoples and Afrodescendants lived in the Pacific (not including the Valle del Cauca department), Atlantic, and Orinoco-Amazon regions, which are considered to have the highest levels of poverty and marginality in Colombia: $76.6 \%$ - indigenous peoples, $54.5 \%$ Afro-descendants, and only $24.7 \%$ for people with no SRE ( $p<0.001$ among the three groups).

With respect to indicators of socio-economic position, although the percentage of informal workers was high overall, indigenous people had the highest rate of informality $(81.7 \%)$, followed by Afro-descendants (67.1\%), and individuals with no SRE $(57.4 \%)$ ( $p<0.001$ between the three groups). Indigenous people also accounted for the highest percentage of those earning less than one current legal monthly minimum wage $(82.1 \%)$, followed by Afro-descendants (70.0\%), and the no-SRE group $(55.7 \%)(p<0.001$ between the three groups). In addition, the indicator 'average years of education' was lowest in indigenous people (7.5), followed by Afro-descendants (9.1), and the no-SRE group (10.4) ( $\mathrm{p}<0.001$ between the three groups).

The indicators of material conditions reflected more disadvantages in indigenous people (38.3\% with some UBNs), followed by Afro-descendants (18.0\%), and the no-SRE group $(8.4 \%)(p<0.001$ between the three groups).

\section{Multifactorial analysis}

No multicolinearity was found between any of the variables (average VIF $=2.63$ ); only a few categories associated with the region of residence had values above 3.0, but they did not exceed the significance threshold (data not shown). Adjustment measures showed an increase in the adjusted $R^{2}$ value to account for the inclusion of blocks of variables associated with social determinants of health, thus suggesting their importance to an explanation of health insurance. All estimated models were globally significant according to the Wald test (Table 3).

The probability of being affiliated with the subsidized insurance regime compared to affiliation with the contributory regime was higher in indigenous people (1.8 times) $(\mathrm{OR}=$ 1.891; 95\%CI: 1.600-2.236) and Afro-descendants (1.4 times) $(\mathrm{OR}=1.415 ; 95 \% \mathrm{CI}: 1.236-1.620)$ than in the no-SRE group $(p$ $<0.01)$. Compared to the no-SRE group, indigenous people and Afro-descendants were 20.2\% (OR = 1.202; 95\%CI: 0.899-1.607) and $5.6 \%(\mathrm{OR}=1.056$; 95\%CI: 0.839-1.329) more likely, respectively, of not being affiliated with any health insurance than to being affiliated with the contributory regime, although the differences were not statistically significant (Table 3).

There was also no observed significant statistical association between ethnic-racial status and type of health insurance, after controlling for four blocks of variables related to the social determinants of health. This association was only significant when comparing the subsidized regime and the contributory regime $(p<0.01)$, which indicates significant inequity due to ethnic-racial status in the population affiliated with the subsidized regime compared to the contributory regime. This reflects significant differences in access to health services and health outcomes among indigenous peoples and Afro-descendants in Colombia; this difference was not observed in the population with no health insurance. This association proved highly significant $(p<0.01)$ based on the five models analyzed, which suggests good model specification and robustness of the effects of ethnic-racial status on type of health insurance.

Sociodemographic factors (area and region of residence) showed greater variation in their association with ethnic-racial status and type of health insurance in indigenous peoples (OR from 6.779 to 2.100) than in Afro-descendants (OR from 2. 445 to 1.573) (Table 3, Block 3).

\section{DISCUSSION}

Several authors have investigated the effect of belonging to an ethnic-racial group on health inequalities (4-7). These results, which focus on inequity due to ethnic-racial status in the type of health insurance in Colombia based on 2019 data, show the effect of ethnic-racial status as a structural component of inequity on access to health services $(8-10,16)$. Even when socio-economic factors are taken into account, indigenous and Afro-descendant populations were more likely to be affiliated with the subsidized regime than the contributory regime, compared to the no-SRE group. In this respect it should be emphasized that ethnic-racial differences between not having insurance and having insurance in the contributory regime were not statistically significant.

After Law 100 was enacted in 1993 (21), programs to improve health system access for vulnerable populations focused on expansion of the subsidized regime. In fact, indigenous communities are particularly prominent in terms of affiliation in the subsidized regime, while other ethnic groups are not explicitly mentioned. Similarly, the Integrated Social Security System has provided for extending coverage to those sectors with insufficient financial capacity, where the indigenous population is one of the priority groups. This has led in part to the disappearance of the association that existed between ethnic-racial status and the probability of not having health insurance. However, the increased likelihood of disadvantaged ethnic-racial groups being affiliated with the subsidized regime could be creating persistent situations of inequity in health service access and health outcomes based on ethnic-racial status in Colombia.

The impact was greater on the indigenous population than on Afro-descendants and the no-SRE group. In fact, indigenous peoples are lagging farther behind in terms of the social determinants of health that could influence access to health services (12). This could be due to a higher incidence of the historical accumulation of inequalities related to health inequity for the most disadvantaged ethnic-racial groups (4-7), despite the positive effect of the universal insurance coverage strategy.

Of the set of socioeconomic factors used to control for the effect of ethnic-racial status on type of health insurance, the area and region of residence showed the greatest variation in inequity due to ethnic-racial status with respect to access to health (27). It should be remembered that ethnic-racial groups, especially indigenous groups, are over-represented in the regions with the most poverty and marginality in Colombia (12). 


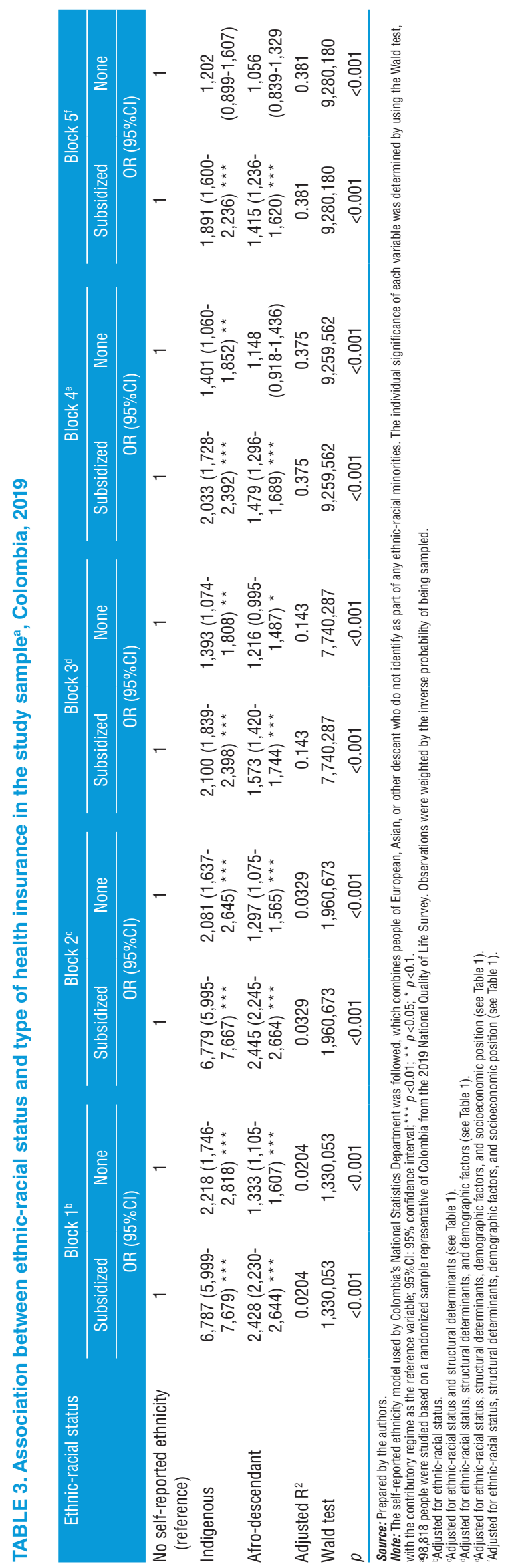


These results are novel because although it was known that ethnic-racial status was associated with the probability of having or not having health insurance $(8-10,16)$, it was not specifically known how significant this actually was in terms of the probabilities of being affiliated with different health insurance regimes. This is particularly novel in the context of improving welfare systems in Latin America based primarily on the universalization of the subsidized regime for vulnerable people (28). It is known that the segmentation between health insurance regimes can lead to disadvantages in accessing health services and the quality of services provided to the subsidized population, and that this may lead to significant inequity in terms of access to health for the most disadvantaged ethnic-racial groups in Colombia (16-19). Most research studies on ethnic-racial status and health inequalities hypothesize that racism and discrimination are factors associated with reduced access to health services and worse health outcomes in the most disadvantaged ethnic-racial groups $(4-10,16,36)$; this could be associated with the current structural discrimination in Colombia. Structural discrimination refers to the "... range of policies and practices that contribute to a systematic disadvantage for members of certain groups" (37).

Nonetheless, it is difficult to capture the cumulative and structural consequences of racism and discrimination through the multifactorial regression analysis used in this study, based on cross-sectional data and adjusting for ethnic-racial status due to socio-economic factors $(32,37)$. However, the empirical evidence accumulated in Colombia shows that ethnic-racial status has a significant effect on factors associated with the social determinants of health $(11,12,16,38-40)$, which could support the hypothesis of cumulative disadvantages and the creation of a vicious cycle of cumulative disadvantages as a factor associated with ethnic-racial inequity in terms of the type of health insurance in Colombia (36).

Several limitations need to be taken into account when interpreting these results. First, it is not possible to establish a causal relationship between the variables studied, particularly the effects that could lead to the historical disadvantages accumulated over generations and the life course of the most disadvantaged ethnic-racial groups. Similarly, the effects of omitted variable bias could not be taken into account when developing the model, which could lead to overestimating or underestimating ethnic-racial discrepancies in the type of health insurance. Furthermore, the reference group consisted of people who did not consider themselves to be indigenous or of African descent but who could still be quite heterogeneous from an ethnic-racial standpoint (for example, including whites and mestizos with greater access to resources, privileges, and power); this could lead to underestimating the association between ethnic-racial status and the type of health insurance in Colombia. However, the use of such a voluminous, nationally representative database with abundant individual information on the social determinants of health strengthens the analysis and the robustness of its conclusions.

\section{Conclusions}

There is a statistically significant association between ethnicracial status and the type of health insurance (subsidized or contributory) in Colombia. These results confirm that ethnicracial status is a structural component of inequity in terms of accessing health services in the country. In the context of the significant segmentation of health insurance regimes in Colombia, ethnic-racial status heightens the disadvantages of individuals and population groups with low socioeconomic status, resulting in less access to and enjoyment of the right to health for the most disadvantaged ethnic-racial groups.

\section{Recommendations}

Once greater health insurance coverage has been achieved through the subsidized regime, access to health and the quality of services must be improved, especially in regions with a larger presence of more disadvantaged ethnic-racial groups where health service delivery is poor. Specific policies and actions that introduce improvements in various areas such as education, labor markets, and housing should be implemented to enhance opportunities to improve the socio-economic status of all ethnic-racial groups in Colombia, thereby increasing equity.

Longitudinal and life-course studies are required to analyze how the effects of discrimination can accumulate across different domains and generations and create a vicious cycle of cumulative disadvantages in accessing health services in Colombia and other countries. In addition, more research is needed to define the true role of health insurance and other social determinants with respect to the ethnic-racial discrepancies that impede access to the health system in Colombia.

Author's contributions. CAVL was responsible for formulating the research problem, methodological design, data analysis, discussion, and final wording of the article; CAVL and GPQ conducted the bibliographic review related to the subject; $\mathrm{ABO}$ participated in the construction of the database, calculation of descriptive statistics, and estimation of multifactorial statistical models. All of the authors reviewed and approved the final version of the manuscript.

\section{Conflicts of interest. None.}

Disclaimer. Authors hold sole responsibility for the views expressed in the manuscript, which may not necessarily reflect the opinion or policy of the Pan American Journal of Public Health and/or the Pan American Health Organization.

\section{REFERENCES}

1. Krieger NA. Glossary for social epidemiology. J Epidemiol Comm Health. 2001;55:693-700 [accessed 25 October 2020]. Available at: http://dx.doi.org/10.1136/jech.55.10.693

2. Flórez CE, Medina C, Urrea F. Understanding the cost of social exclusion due to race or ethnic background in Latin America and
Caribbean countries. Washington, DC: Inter-American Development Bank; 2001.

3. Solar O, Irwin A. A conceptual framework for action on the social determinants of health. Social Determinants of Health Discussion Paper 2 (Policy and Practice). Geneva: World Health Organization; 
2010 [accessed 28 October 2020]. Available at https://apps.who. int/iris/handle/10665/44489

4. Nazroo JY, Williams DR. The social determination of ethnic/racial inequalities in health. En: Nazroo JY, Marmot M, Wilkinson RG, eds. The social determination of ethnic/racial inequalities in health. Social Determinants of Health. 2nd ed. London: Oxford University Press; 2005.

5. Torres-Parodi C, Bolis M. Evolución del concepto etnia/raza y su impacto en la formulación de políticas para la equidad. Rev Panam Salud Publica. 2007;22(6):405-16 [accessed 15 July 2020]. Available at: http://www.scielosp.org/scielo.php?script= sci_arttext\&pid=S1020-49892007001100009

6. Williams DR, Mohammed SA. Discrimination and racial disparities in health: Evidence and needed research. J Behav Med. 2009;32:20-47 [accessed 13 October 2020]. Available at: https:/ / doi. org/10.1007/s10865-008-9185-0

7. Williams DR: Lawrence JA, Davis BA. Racism and health: Evidence and needed research. Annu Rev Public Health. 2019;40:105-25 [accessed 14 October 2020]. Available at: https://doi.org/10.1146/ annurev-publhealth-040218-043750

8. Lillie-Blanton M, Hoffman C. The role of health insurance coverage in reducing racial/ethnic disparities in health care. Health Aff. 2005;24(2):398-408. doi:10.1377/hlthaff.24.2.398

9. Kirby JB, Kaneda T. Unhealthy and uninsured: Exploring racial differences in health and health insurance coverage using a life table approach. Demography. 2010;47:1035-51. doi:10.1007/BF03 213738

10. Sohn H. Racial and ethnic disparities in health insurance coverage: Dynamics of gaining and losing coverage over the life-course. Popul Res Policy Rev. 2017;36(2):181-201 [accessed 14 October 2020]. Available at: https:/ / doi.org/10.1007/s11113-016-9416-y

11. Viáfara-López CA. Diferencias raciales en las oportunidades educativas y ocupacionales en el primer empleo en la ciudad de Cali, Colombia [master's thesis]. Mexico DF: FLACSO Mexico; 2005.

12. Urrea F, Viáfara C. Pobreza y minorías étnicas en Colombia: un análisis de sus factores determinantes y lineamientos de política para su reducción. Misión para el diseño de una estrategia para la reducción de la pobreza y la desigualdad. Bogotá: Departamento Nacional de Planeación de Colombia; 2007.

13. Urrea F, Bergonzoli G, Carabalí B, Muñoz VH. Patrones de mortalidad comparativos entre la población afrodescendiente y la blancamestiza para Cali y el Valle. Rev CS [Internet]. 2015;(16):131-67 [accessed 28 September 2020]. Available at: https:// www.icesi.edu. co/revistas/index.php/revista_cs/article/view/1961

14. Agudelo-Suárez A, Martínez-Herrera E, Posada-López A, Rocha-Buelvas A. Ethnicity and health in Colombia: What do selfperceived health indicators tell us? Ethn Dis. 2016;26(2):147-56. doi:10.18865/ed.26.2.147

15. Tovar LM, Perea LN, Tovar JR, Zúñiga CL. Determinantes sociales de la salud autorreportada: Colombia después de una década. Mundo Saude (São Paulo). 2018;42(1):230-47. doi: 10.15343/ 0104-7809.20184201230247

16. Bernal R, Cárdenas M. Race and ethnic inequality in health and health care in Colombia. Bogotá: Fedesarrollo; 2005.

17. Ayala J. La salud en Colombia: más cobertura, pero menos acceso. Documentos de trabajo sobre Economía Regional. Cartagena: Banco de la República, Sucursal Cartagena; 2014.

18. Hurtado-Saa T, Rosas-Vargas R, Valdés-Cobos A. Servicios de salud, discriminación y condición étnica/racial: un estudio de caso de la problemática en México y Colombia. Ra Ximhai. 2013;9(1):135-51.

19. Ariza-Montoya J, Hernández-Álvarez M. Equidad de etnia en el acceso a los servicios de salud en Bogotá, Colombia, 2007. Rev Salud Publica. 2008;10(Suppl 1):58-71.

20. Aday LA, Andersen R. A framework for the study of access to medical care. Health Serv Res. 1974;9(3):208-20.

21. Congreso de la República de Colombia. Ley 100 de 1993, del 23 de diciembre, por la cual se crea el Sistema de Seguridad Social Integral y se dictan otras disposiciones. Bogotá: Imprenta Nacional; 1993.

22. Londoño JL, Nieto E. Factores socio económicos y aseguramiento en salud en el área urbana de Colombia. Rev Fac Nac Salud Publica [internet]. 2001;19(1):25-40 [accessed 18 October 2020]. Available at: https://www.redalyc.org/articulo.oa?id=12019103
23. Giedion U, Uribe MV. Colombia's universal health insurance system. Health Aff (Millwood). 2009;28(3):853-63 [accessed 31 October 2020]. doi: https://doi.org/10.1377/hlthaff.28.3.853

24. García-Subirats I, Vargas-Lorenzo I, Mogollón-Pérez AS, De Paepe P, Ferrera Da Silva RM, Unjer JP, et al. Determinantes del uso de distintos niveles asistenciales en el Sistema General de Seguridad Social en Salud y Sistema Único de Salud en Colombia y Brasil. Gac Sanit. 2015;28:480-8 [accessed 1 November 2020]. Available at: https://doi.org/10.1016/j.gaceta.2014.05.010

25. Mejía-Mejía A, Sánchez-Gandur A, Tamayo-Ramírez JC. Equidad en el acceso a servicios de salud en Antioquia, Colombia. Rev Salud Publica. 2007;9(1):26-38 [accessed 11 October 2020]. Available at: http://www.scielo.org.co/scielo.php?script=sci_arttext \&pid=S0124-00642007000100005\&lng=en

26. Hilarión-Gaitán L, Díaz-Jiménez D, Cotes-Cantillo K, CastañedaOrjuela C. Desigualdades en salud según régimen de afiliación y eventos notificados al Sistema de Vigilancia (Sivigila) en Colombia, 2015. Biomedica. 2019;39(4):737-47 [accessed 29 October 2020]. Available at: https://revistabiomedica.org/index.php/biomedica/ article/view / 4453

27. Vargas-Lorenzo I, Vázquez-Navarrete ML, Mogollón-Pérez A. Acceso a la atención en salud en Colombia. Rev Salud Publica. 2010;12(5):701-12 [accessed 29 October 2020]. Available at: http:/ / www.scielo.org.co/scielo.php?script=sci_arttext\&pid= S0124-00642010000500001\&lng=en

28. Abramo L, Cecchini S, Ullmann H. Addressing health inequalities in Latin America: The role of social protection. Cienc Saude Colet. 2020;25(5):1587-98 [accessed 15 July 2020]. Available at: https:// doi.org/10.1590/1413-81232020255.32802019

29. Departamento Nacional de Estadística (DANE). Encuesta Nacional de Calidad de Vida 2019. Bogotá: DANE; 2020.

30. Ministerio del Trabajo. Decreto 2451 del 27 de diciembre de 2018. Bogotá: Mintrabajo; 2018.

31. Banco de la República. Tasa representativa de mercado [Internet]. Bogotá: Banrep; 2019 [accessed 20 November 2020]. Available at: https://www.banrep.gov.co/es/estadisticas/trm

32. Blank RM, Dabady M, Citro CF, eds. Measuring racial discrimination. Washington, DC: National Research Council; 2004 [accessed 17 July 2020]. Available at: https://doi.org/10.17226/10887

33. Kaufman JS, Cooper RS. Commentary: considerations for use of racial/ethnic classification in etiologic research. Am J Epidemiol. 2001;154(4):291-8.

34. Hair JF, Babin BJ, Anderson RE, Black WC. Multivariate data analysis. $8^{\text {th }}$ ed. Cengage, Reino Unido: Cengage; 2019.

35. StataCorp. Stata statistical software: Release 16. College Station, TX: StataCorp LLC; 2019.

36. Phelan J, Link B. Is racism a fundamental cause of inequalities in health? Rev Sociology. 2015;41:311-30 [accessed 21 October 2020]. Available at: https:/ / doi.org/10.1146/annurev-soc-073014-112305

37. Pager D, Shepherd H. The sociology of discrimination: Racial discrimination in employment, housing, credit, and consumer markets. Annu Rev Sociol. 2008;34:181-209 [accessed 21 October 2020]. Available at: https: / / doi.org/10.1146/annurev.soc.33.040406.131740

38. Viáfara-López CA, Urrea Giraldo F. Efectos de la raza y el género en el logro educativo y estatus socio-ocupacional para tres ciudades colombianas. Desarrollo Soc. 2006;(58):115-63.

39. Pérez L, Mora Jhon J. La calidad del empleo en la población afrodescendiente colombiana: una aproximación desde la ubicación geográfica de las comunas. Rev Econ Rosario. 2014;17(2):315-47 [accessed 20 July 2020]. Available at: https://revistas.uro-sario.edu. co/index.php/economia/article/view/3748

40. Viáfara López CA. Diferenciales de ingreso por el color de la piel y desigualdad de oportunidades en Colombia. Rev Econ Rosario. 2017;20(1):97-126 [accessed 20 July 2020] Available at: https:// revistas.urosario.edu.co/index.php/economia/article/view/6151

Manuscript received on 21 July 2020. Revised version accepted for publication on 9 November 2020. 


\section{Inequidad por la condición étnico-racial en el aseguramiento de salud en Colombia: un estudio de corte transversal}

RESUMEN Objetivo. Caracterizar la relación entre la inequidad por la condición étnico-racial y el tipo de aseguramiento de salud en Colombia.

Métodos. Estudio de corte transversal basado en datos de la Encuesta de Calidad de Vida 2019. Se analizó el tipo de aseguramiento de salud (contributivo, subsidiado o ninguno) y su relación con la condición étnicoracial y variables predisponentes (sexo, edad, estado civil), demográficas (zona y región de residencia) y socioeconómicas (educación, tipo de empleo, ingresos y necesidades básicas insatisfechas) mediante análisis de regresión simple y multifactorial. La asociación entre la condición étnico-racial y el tipo de aseguramiento de salud fue estimada utilizando razones de posibilidades (OR) y sus intervalos de confianza de $95 \%$, mediante un modelo logístico multinomial.

Resultados. Se encontró asociación estadísticamente significativa entre la condición étnico-racial y el tipo de aseguramiento de salud. En comparación con el régimen contributivo, las probabilidades de estar afiliado al régimen subsidiado fueron 1,8 y 1,4 veces mayores en los indígenas ( $O R=1,891 ;$ IC95\%: 1,600-2,236) y afrodescendientes (OR $=1,415$; IC95\%: 1,236-1,620), respectivamente $(p<0,01)$, que el grupo de la población que no se reconoció como perteneciente a uno de esos grupos étnico-raciales.

Conclusiones. Existe una asociación entre la condición étnico-racial y el tipo de aseguramiento en el régimen contributivo y subsidiado de salud en Colombia. La condición étnico-racial se manifiesta como un componente estructural de la inequidad en el acceso a los servicios de salud y profundiza las desventajas de las personas y grupos poblacionales con un bajo estatus socioeconómico.

Palabras clave Accesibilidad a los servicios de salud; determinantes sociales de la salud; factores socioeconómicos; inequidad étnica; Colombia.

\section{Iniquidades étnico-raciais no seguro de saúde na Colômbia: um estudo transversal}

RESUMO Objetivo. Caracterizar a relação entre as iniquidades étnico-raciais e o tipo de seguro de saúde na Colômbia. Métodos. Estudo transversal realizado com dados da Pesquisa de Qualidade de Vida 2019. Analisou-se o tipo de seguro de saúde (contributivo, subsidiado ou inexistente) e sua relação entre a condição étnicoracial e variáveis predisponentes (gênero, idade, estado civil), demográficas (zona e região de residência) e socioeconômicas (nível de escolaridade, tipo de emprego, renda e necessidades básicas não atendidas) por regressão simples e multifatorial. Estimou-se a associação entre a condição étnico-racial e o tipo de seguro de saúde em um modelo de regressão logística multinomial com razão de possibilidades (OR) e os respectivos intervalos de confiança de 95\%.

Resultados. Observou-se uma associação estatisticamente significativa entre a condição étnico-racial e o tipo de seguro de saúde. Em comparação ao esquema contributivo, a probabilidade de um indivíduo ser associado ao esquema subsidiado foi 1,8 e 1,4 vez maior entre indígenas (OR = 1,891; IC95\%: 1,600-2,236) e afrodescendentes (OR =1,415; IC95\%: 1,236-1,620), respectivamente $(p<0,01)$ que no grupo populacional que não se declarou pertencer a um destes grupos étnicos-raciais.

Conclusões. Existe uma associação entre a condição étnico-racial e o tipo de seguro de saúde nos esquemas contributivo e subsidiado na Colômbia. A condição étnico-racial constitui um componente estrutural da iniquidade no acesso aos serviços de saúde aprofundando as desvantagens das pessoas e grupos populacionais com nível socioeconômico baixo.

Palavras-chave Acesso aos serviços de saúde; determinantes sociais da saúde; fatores socioeconômicos; iniquidade étnica; Colômbia. 